\title{
RECONSIDERING THE INTERDEPENDANCE OF AIR TRANSPORT AND TOURISM IN THE CONTEXT OF THE GLOBAL COVID-19 PANDEMIC
}

\author{
Mijana Matošević Radić ${ }^{1}$ \\ Matea Bralić
}

\begin{abstract}
Transport and tourism are interdependent, since the development of tourism is influenced by the development of transport but at the same time it affects the development of transport.The improvement of air transport has enabled faster, safer and more comfortable connection of generating countries and destinations, which has a positive impact on the development of tourism. On the other hand, the increase in tourist demand encourages the further development of transport and means of transport are being developed for tourist purposes. The aim of this paper is to investigate whether the role of air transport in tourism has changed in the context of the global COVID-19 pandemicand also in which direction it will develop changes. In order to investigate the changing role of air transport in tourism, a three-step analysis was conducted. The first step analyses the interdependence of tourism and air transport in the period before the global pandemic. In the second step, the impact of the COVID-19 pandemic on air transport and consequently on tourism is investigated. While the third step predicts the consequences that this pandemic could have on air transport and tourism. The results of the analysis showed that the interdependence of air transport and tourism is stable even in conditions of global crises (such as a pandemic). However, it can be expected that both air transport and tourism will experience changes, both in the area of safety standards and in the area of new product development.
\end{abstract}

Key words: air transport, tourism, COVID-19 pandemic, safety, new product development

\section{INTRODUCTION}

Since its foundation, air transport and tourism have always been interconnected, strongly influencing each other (Stonescu, 2017).Transportin general is one of the main components of the tourism product at both macro and micro levels (Papatheodorou and Zenelis, 2013). At the macro level the role of transport arises from different possibilities of connecting the country of origin and the tourist destination, while at the micro level the organization of transport in the tourist destination is observed. Same modes of transport if combined with some natural or social factor, and in some cases separately, can be a tourist attraction.

Although each form of transport has a certain role in the development of tourism, the role of air transport can be considered the most important, primarily due to the fact that an increasing number of international tourists take aircraft to arrive at the destination. According to UNWTO data (2019), the share of air travel has increased from $46 \%$ in 2000 to $58 \%$ in 2018.

\footnotetext{
${ }^{1}$ Senior Lecturer, University of Split, University Department of Professional Studies, Kopilica 5, 21000 Split, Croatia.

${ }^{2}$ Student, University of Split, University Department of Professional Studies, Kopilica 5, 21000 Split, Croatia.
} 
The possibilities of air transport in meeting tourist needs are determined by the size and condition of transport infrastructure and means of transport, as well as their ability to meet the demands of their services for the quality of services such as safety, comfort and transport costs (Bukvić, 2003). An important factor that encourages the development of passenger air transport for tourism purposes is the safety of this mode of transport, as air transport is one of the safest modes of transport (Zajac, 2016).

Air transport, however, also has certain disadvantages, including: dependence on natural environmental conditions, which sometimes jeopardize the possibility of obtaining travel plans, a certain level of risk, large investments necessary for the organization and modernization of the airports. It is also important to emphasize that air transport has a strong impact on fuel shortages, terrorism, economic and political crises (Georgescu, 2016).

However, the development of tourism sometimes depends entirely on the development and availability of air transport. Air transport is crucial for long haul destination, because it allows the fastest and most efficient connection between the generating market and very distant destinations. Also, the development of air transport in recent years has contributed to the development of tourism, by encouraging the development of new forms of tourism and tourism products.

At the same time there is a reciprocal impact of tourism on air transport in such a way that the increase in tourist demand in the destination motivates airlines to develop the infrastructure and organization of air transport. Furthermore, with the development of air transport in the destination, the destination becomes more accessible to tourists, which generates new tourist demand and encourages further development of tourism (Stonescu, 2017).

\section{IMPACT OF COVID-19 PANDEMIC ON AIR TRANSPORT AND TOURISM}

\section{Impact of COVID-19 pandemic on air transport}

In order to prevent the spread of diseases caused by coronavirus many countries have closed their borders or introduced strict travel restriction, which has reduced air transport globally by more than $40 \%$.

According to Eurostat data, that are shown in Table 1, the largest decrease in the number of passengers in March 2020 compared to March 2019 was recorded in Italy (which achieved $85 \%$ less air transport compared to the previous year, which means that transported 11.9 million fewer passengers in March 2020 compared to the same month in previous year), Germany (where air traffic was reduced by $62 \%$ which means that in absolute terms there was a decrease of 10.7 million transported passengers), Denmark (which carried 1.7 million fewer passengers in March 2020 compared to the same month In 2019, or 63\% less), Finland (which carried 1.1. million fewer passengers that is, it achieved relative decline in the amount of $57 \%$ compared to the same month last year), and Hungary (which in March 2020 transported 0.7 million passengers compared to March 2019, which represent a reduction in air traffic by $58 \%$ ).

Since in March 2020 all these countries were already facing the spread of coronavirus disease, passengers are not allowed to travel or are discouraged from doing it so because they must be quarantined due to restrictions in the countries they come to. For these reasons, travel in these circumstances is limited mainly to business travel. 
However, Cargo traffic has not been significantly affected by the pandemic, and in some countries, there has even been increased traffic due to the supply of medical equipment to fight against this disease.

Although the data on air traffic in March 2020 are extremely unfavourable, if we analyse the second quarter of the same year, the situation is even more dramatic. As we can see from the data presented in Table 1, the most unfavourable situation was in North Macedonia, which achieved almost $100 \%$ less passenger air transport compared to the second quarter of 2019.

Table 1. Passengers in air transport in selected countries

\begin{tabular}{|l|r|r|r|r|r|r|}
\hline \multicolumn{1}{|c|}{ Country } & $\begin{array}{c}\text { March } \\
\mathbf{2 0 1 9} \\
\mathbf{( 0 0 0 )}\end{array}$ & $\begin{array}{c}\text { March } \\
\mathbf{2 0 2 0} \\
\mathbf{( 0 0 0 )}\end{array}$ & $\begin{array}{c}\text { March } \\
\mathbf{2 0 1 9 /} \\
\text { March } \\
\mathbf{2 0 2 0}\end{array}$ & $\begin{array}{c}\text { Q2 2019 } \\
\mathbf{( 0 0 0 )}\end{array}$ & $\begin{array}{c}\text { Q2 } \\
\mathbf{2 0 2 0} \\
\mathbf{( 0 0 0 )}\end{array}$ & $\begin{array}{c}\text { Q2 } \\
\mathbf{2 0 1 9 / Q 2} \\
\mathbf{2 0 2 0}\end{array}$ \\
\hline Croatia & 306 & 119 & $\downarrow 61 \%$ & 3.216 & 86 & $\downarrow 97 \%$ \\
\hline Cyprus & 564 & 231 & $\downarrow 59 \%$ & 3.286 & 56 & $\downarrow 98 \%$ \\
\hline Denmark & 2652 & 979 & $\downarrow 63 \%$ & 9.361 & 252 & $\downarrow 97 \%$ \\
\hline Finland & 1.888 & 808 & $\downarrow 57 \%$ & 6.090 & 143 & $\downarrow 98 \%$ \\
\hline Germany & 17.193 & 6.504 & $\downarrow 62 \%$ & 61.039 & 1.987 & $\downarrow 97 \%$ \\
\hline Hungary & 1.206 & 509 & $\downarrow 58 \%$ & 4.368 & 118 & $\downarrow 97 \%$ \\
\hline Iceland & 614 & 231 & $\downarrow 62 \%$ & 1.928 & 61 & $\downarrow 97 \%$ \\
\hline Lithuania & 467 & 203 & $\downarrow 57 \%$ & 1.766 & 48 & $\downarrow 97 \%$ \\
\hline Luxembourg & 321 & 128 & $\downarrow 60 \%$ & 1.185 & 37 & $\downarrow 97 \%$ \\
\hline North Macedonia & 164 & 72 & $\downarrow 56 \%$ & 602 & 2 & $\downarrow 100 \%$ \\
\hline Norway & 3.231 & 1.399 & $\downarrow 57 \%$ & 10.534 & 1.085 & $\downarrow 90 \%$ \\
\hline Slovakia & 170 & 46 & $\downarrow 73 \%$ & 691 & 4 & $\downarrow 99 \%$ \\
\hline Slovenia & 133 & 36 & $\downarrow 73 \%$ & 516 & 5 & $\downarrow 99 \%$ \\
\hline Switzerland & 4.711 & 1.791 & $\downarrow 62 \%$ & 14.962 & 363 & $\downarrow 98 \%$ \\
\hline
\end{tabular}

Source: adapted by the authors according to:European Commission, Eurostat, Air

Passenger Transport in March 2020, available at:

https://ec.europa.eu/eurostat/documents/4187653/10321603/Air transport 3.jpg/2231

3c18-004d-66bb-13ae-4332b907e606?t=1592245321622 and European Commission,

Impact of COVID-19 on air passenger transport in Q2 2020, available at:

https://ec.europa.eu/eurostat/web/products-eurostat-news/-/DDN-20201015-2

However, the largest decline in the number of passengers was recorded in Germany (59.1 million fewer passengers were transported in the second quarter of 2020, which is a decrease of $97 \%$ compared to the second quarter of 2019). Switzerland (recorded a decrease of 14.6 million, compared to the second quarter of 2019, which is a decrease of air transport by $98 \%$ ) and Norway (which had a turnover of 9.5 million passengers, that is a decrease of $90 \%$ compared to the second quarter of 2019). It cannot be overlooked that all these countries (except Norway) in the second quarter of 2020 were faced with a decline in passenger air transport of more than $95 \%$.

In order to conduct a more detailed analysis, which can explain more comprehensively the movement of passenger air transport during the pandemic, we examine monthly data 
at the two largest airports in Croatia: Zagreb airport and Split airport, which is extremely interesting for detailed analysis due to the high share of tourism in gross domestic product in Croatia.

Zagreb airport is typical commercial airport with more than 3.4 million passengers per year, with over 45.000 flights per year, while Split airport is seasonal airport that has the certain seasonal fluctuations with more than 3.3 million passengers per year. Split airport reaches its peak in the summer months, while Zagreb airport has balanced traffic through the year.

The effect of the pandemic is visible at both airports, where the airport Split is more severely affected because of its seasonality. At both airports, traffic was gradually reduced from February to April where most European Union member states applied strict travel restrictions.

Table 2. Passengers in air transport in Croatia

\begin{tabular}{|l|c|r|r|r|r|r|}
\hline & \multicolumn{3}{|c|}{ Zagreb airport } & \multicolumn{3}{c|}{ Split airport } \\
\cline { 2 - 7 } & $\mathbf{2 0 1 9 .}$ & \multicolumn{1}{c|}{$\mathbf{2 0 2 0 .}$} & \multicolumn{1}{c|}{ \% } & \multicolumn{1}{c|}{$\mathbf{2 0 1 9 .}$} & \multicolumn{1}{c|}{ 2020. } & \multicolumn{1}{c|}{$\%$} \\
\hline January & 191.197 & 203.035 & $\uparrow 5,83$ & 36.360 & 36.741 & $\uparrow 1,03$ \\
\hline February & 181.154 & 184.236 & $\uparrow 1,67$ & 34.825 & 26.294 & $\downarrow 24,50$ \\
\hline March & 232.978 & 97.063 & $\downarrow 58,34$ & 50.037 & 16.466 & $\downarrow 67,09$ \\
\hline April & 280.790 & 5.118 & $\downarrow 98,18$ & 156.381 & 6 & $\downarrow 100,00$ \\
\hline May & 311.368 & 13.881 & $\downarrow 95,54$ & 310.809 & 2.777 & $\downarrow 99,11$ \\
\hline June & 336.618 & 44.402 & $\downarrow 86,81$ & 513.706 & 26.150 & $\downarrow 94,91$ \\
\hline July & 366.242 & 78.070 & $\downarrow 78,68$ & 723.048 & 173.617 & $\downarrow 75,99$ \\
\hline August & 376.026 & 93.553 & $\downarrow 75,12$ & 672.262 & 273.842 & $\downarrow 59,27$ \\
\hline September & 350.138 & 65.963 & $\downarrow 81,16$ & 470.102 & 75.881 & $\downarrow 83,86$ \\
\hline
\end{tabular}

Source: adapted by the authors according to: Zagreb Airport,Statistics for 2020, available at: https://www.zagreb-airport.hr/poslovni/b2b-223/statistika/statistika-za2020-godinu/628 and Split Airport, Statistics, available at: http://www.splitairport.hr/index.php?option=com_content\&view= $\underline{\text { article } \& \text { id }=160 \& \text { Itemid }=115 \& \text { lang }=\mathrm{hr}}$

The most critical month for both airports was April. In April 2019, 280.790passengers passed through Zagreb airport, while in April 2020 it's been 5.118 passengers, which is a decreased compared to last year by $98,18 \%$. An even more dramatic situation was at the airport in Split, through which more than $99.9 \%$ fewer passengers passed in April 2020 compared to the same month last year.

The only exception is February in the case of Zagreb airport, where there was a slight increase in traffic by $1,67 \%$ compared to February last year, and this increase is attributed to the increased number of passengers returning to their home countries because of the restrictions (Nižetić, 2020).

Through Zagreb airport in July this year, 78.070 passengers passed, which is 33.668 passengers more than in June. However, compared to July last year, there was a significant decline as in the same month last year, where 366.242 passengers passed through Zagreb airport. In the same month, Split airport carried 173.617 passengers. This is a significant increase compared to June, when only 26.150 passengers passed through Split airport. However, when the data are compared to the previous year, Split 
airport also faces a significant reduction in traffic, as in July 2019, 723.048 passengers passed through Split airport, approximately half a million more passengers than in July this year.

From the data presented in Table 2. it can be spotted that a slightly smaller decrease in the number of transported passengers (compared to the reduction achieved in the remaining months of the year) was achieved in July and August in the case of Split airport, primarily due to the opening of borders and the reduction of restrictions in the movement which resulted in the inducing of tourist movements. However, as the epidemiological situation worsened in the second half of August, generatingmarkets introduced restrictions on movement and passenger air transport again fell sharply compared to the data from the previous year.

\section{Impact of tourism cutting down on air transport caused by COVID-19 pandemic}

As a result of the COVID-19 pandemic, international tourism has been completely suspended, and domestic tourism has been blackout due to strict restrictions in many countries. Although some destinations have begun to open slowlyin June and July, many people felt the fear of travel or cannot have enough money for it due to the economic crisis.

In 2019, the tourism sector was responsible for $29 \%$ of total services exports worldwide and about 300 million jobs globally (UNWTO, 2019). International tourism is an important source of income and employment for developed and developing countries. Globally, tourism arrivals could have devastating economic consequences as some developing countries depend on tourism only in some regions slowly for the summer (UNCTAD, 2020).

Table 3. Foreign tourist arrivals in Croatia (000)

\begin{tabular}{|l|r|r|r|}
\hline & \multicolumn{1}{|c|}{2019.} & \multicolumn{1}{|c|}{2020.} & \multicolumn{1}{c|}{$\%$} \\
\hline January & 119 & 123 & $\uparrow 3,25$ \\
\hline February & 170 & 172 & $\uparrow 1,16$ \\
\hline March & 318 & 61 & $\downarrow 80,82$ \\
\hline April & 933 & 1 & $\downarrow 100,00$ \\
\hline May & 1.353 & 32 & $\downarrow 97,63$ \\
\hline June & 2.672 & 642 & $\downarrow 75,97$ \\
\hline July & 4.033 & 1.968 & $\downarrow 51,20$ \\
\hline August & 4.365 & 2.056 & $\downarrow 52,90$ \\
\hline
\end{tabular}

Source: adapted by the authors according to the data obtained from Republic of Croatia - Croatian Bureau of Statistics, available at:https://www.dzs.hr/default.htm

At the beginning of March, the governments of many countries have introduced a series of measures aimed at restraining the spread of a COVID-19 pandemic such as quarantine, with an emphasis on improving public health services and closing borders. International tourism is one of the economic sectors most affected by the COVID-19 pandemic. UNWTO (2020) estimates a reduction in international tourist arrivals of 850 million to 1.1 billion globally, a decline in tourism revenues of 910 million to 1.1 trillion dollars and the loss of 100-120 million jobs in the industries that make up the world's 
tourism system, depending on whether the borders open in July, September or December. Most destinations were completely closed in April and May 2020, opening In the second half of May tourism is being launched responsibly around the world, as an increasing number of destinations are easing travel restrictions related to COVID-19 and adapting to the new reality. According to an analysis by the World Tourism Organization (UNWTO), $40 \%$ of all world destinations over the summer eased restrictions imposed on international tourism in response to preventing the spread of the COVID-19 pandemic.

Table 3 shows the comparison of realized tourist arrivals of foreign tourists to Croatia in 2019 and 2020 by months. There is no doubt that the COVID-19 pandemic has significantly affected the reduction of passenger air transport, especially in Croatia where the largest share of air passenger transport is due to foreign tourists who choose Croatia as their holiday destination (Gašparović, 2011). The impact of tourism on air transport in Croatia is evident from the data on tourist transport in Croatia, where it is pointed out that higher tourist movement is realized by destinations that are closer to generating markets by road (such as Istria) and that destinations that depend on tourists who come mainly by plane (such as Dubrovnik) more modest figures.

\section{PREDICTIONS OF THE RELATIONSHIP BETWEEN AIR TRANSPORT AND TOURISM IN THE PERIOD AFTER THE COVID-19 PANDEMIC}

Although, as a rule, the combined influence of tourism and air transport was proved on the upward trends oftheir development, which led to mutually supportive development, the previous chapter showed that there is also a resilientrelationship in the downward trend. However, the COVID-19 pandemic situation is not the first such example in the world.

After an eruption of Eyjafjallajokull in Iceland in April 2010, due to the cloud of volcanic ash, air traffic in most parts of Europewas suspendedin a week. It is estimated that due to the unplanned suspension of air transport, the air transport sector made a loss of more than 3.3 billion $\$$, while the loss of the tourism industry as a whole is many times higher (Zajac, 2016).

Also, the impact of insecurity and increased safety risk on air transport and tourism is unquestionable.

Street riots and demonstrations with which Egypt was faced in early 2011 caused a short-term suspension of air transport many carriers to world famous destinations such as Sharm-el-Sheikh. Although the situation stabilized relatively quickly, shooting down planes of the Russian air carrier Metrojet in the second half of 2015 again reactivated the air carriers' distrust. Perhaps the most significant long-term impact on air transport and tourism was the terrorist attack on the World Trade Centre in the United States on September 11, 2001, followed by increased security checks on passengers and luggage and modernized and enforced security procedures at airports around the world.

All these examples prove that both air transport and tourism have recovered after both natural and safety challenges. The same is expected after the COVID-19 pandemic. However, it is almost confident that certain consequences will remain. They will have the most prominent impact on the health checks of passengers and staff (in the phase of gradual recovery of tourism as long as there is a risk of endangering the health of passengers). 
On the other hand, tourism will also experience certain adjustments. Rising awareness of sustainable tourism will increase the demand for certain forms of tourism, such as rural tourism, and decision-makers will be forced to manage development by looking for ways to limit over tourism. Tourist demand is already slowly turning to accommodation facilities in isolated areas, reducing interest in overcrowded areas. At the same time, responsible and sustainable business of airlines is extremely important, which should not return to the old business models. The profit motive that connected them with tour operators in the past, which resulted in overcrowding of some destinations to tourists, must now be reconsidered. As tourists become increasingly aware of the importance of sustainable development, airlines must find a way to improved disperse of passengers to more isolated destinations and find ways to do business economically by using smaller passenger aircrafts. This opens the possibility of creating a completely new tourist product which, following the example of urban areas with modern airport infrastructure, will make isolated unpopulated areas accessible to a significantly smaller number of passengers.

\section{CONCLUSION}

The interdependence of air transport and tourism has been the subject of numerous analyses, which have mainly argued that there is a correlation between the number of air transport passengers and the tourist arrivals in the conditions of both air transport and tourism growth. This analysis focused on reconsidering the interdependence of tourism and air transport in the recent situation of increased safety risk caused by the COVID-19 pandemic.

The results of the conducted research showed that there is a stable correlation between air transport and tourism even if air transport and tourism are reduced. Although measures to prevent the spread of the pandemic have significantly reduced air transport and tourism, examples of similar situations from the past (caused by natural and security risks) give hope and optimism. As the spread of COVID-19 disease is curbed, tourism is expected to reopen, that will stimulate air transport which had to support reopening of tourism.

However, it should not expect a return to the old state. Due to the up-to-date situation, all stakeholders in tourism must change their worldview and focus more passionately on sustainable development.Airlines will need to develop and implement new health and safety standards, but also make an effort on developing products that will meet the new needs of tourism demand.

\section{LITERATURE}

1. Bukvić, I. (2003). Utjecaj zračnog prometa na razvoj turizma dubrovačkog područja. Naše more, 50 (3-4), 125-136.

2. European Commission, Eurostat, Air Passenger Transport in March 2020., available at:

https://ec.europa.eu/eurostat/documents/4187653/10321603/Air transport 3.jpg/2

2313c18-004d-66bb-13ae-4332b907e606? $\mathrm{t}=1592245321622$ 
3. European Commission, Impact of COVID-19 on air passenger transport in Q2 2020, available at: https://ec.europa.eu/eurostat/web/products-eurostat-news//DDN-20201015-2

4. Gašparović, S. (2011). Zračni promet i turizam primorske Hrvatske. Geoadria, $16 / 2,155-187$

5. Georgescu, C. (2016). The role of air transport in international tourism. Knowledge Horizons - Economics, 8 (1), 151-153.

6. Nižetić, S. (2020). Impact of coronavirus (COVID-19) pandemic on air transport mobility, energy, and environment: A case study. International Journal of Energy Research, 44, 10953-10961.

7. Papatheodorou, A., Zenelis, P. (2013). The importance of the air transport sector for tourism. in: Tisdell, C. A. (ed.). Handbook of tourism economics. Singapore: World Scientific Publishing

8. Split Airport, Statistics, available at: http://www.splitairport.hr/index.php?option=com content\&view=article \&id=160\&Itemid=115\&la $\underline{n g}=\mathrm{hr}$

9. Stonescu, C. (2017). New perspectives of the tourism and air travel relation., Cactus Tourism Journal, 15 (2), 24-32.

10. United Nations Conference on trade and development (UNCTAD) (2020). Covid19 and tourism: Assessing the economic consequences, available at: https://unctad.org/en/PublicationsLibrary/ditcinf2020d3 en.pdf

11. United Nations World Tourism Organization (UNWTO) (2019). International Tourism Hightlights, 2019. Edition, available at: https://www.eunwto.org/doi/pdf/10.18111/9789284421152

12. Zagreb Airport, Statistics for 2020, available at: https://www.zagrebairport.hr/poslovni/b2b-223/statistika/ statistika-za-2020-godinu/628

13. Zajac, G. (2016). The role o fair transport in the development of international tourism. Journal of International Trade, Logistics and Law, 2 (1), 1-8. 